\section{Voksfigurer, medisinsk historie og kunst}

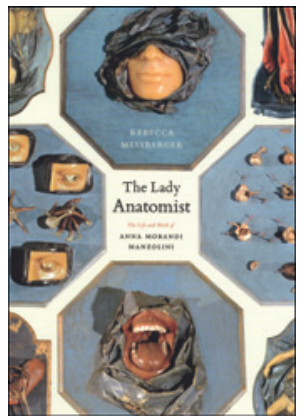

Rebecca Messbarger

The lady anatomist

The life and work of Anna Morandi Manzolini. 234 s, ill. Chicago, IL: The University of Chicago Press, 2010. Pris USD 35 ISBN 978-0-226-52081-0

Voks, oftest bivoks blandet med forskjellige oljer og farger, er et fint materiale å lage figurer i. Voks kan farges og modelleres ganske greit. Det finnes i dag flere store vokskabinetter, og Madame Tussauds er vel det mest kjente. Men allerede i middelalderen, og spesielt i opplysningstiden, ble voksfigurer brukt $i$ anatomiundervisningen. I sykehusmuseer kan man finne naturtro voksfigurer, modellert etter både levnede og døde pasienter.

Rebecca Messbarger er professor i italiensk og kvinnehistorie ved Washington University i St. Louis. I boken om den italienske anatomen Anna Morandi Manzolini (1714-74) har hun bokstavelig talt børstet støvet av gamle, praktfulle kunstverk i voks.

Denne utgivelsen er ikke bare en biografi om Anna Morandi, men også en interessant beskrivelse av livet i universitetsbyen Bologna på 1700-tallet. Paven hadde eget museum i byen. Kunst, vitenskap og religion ble oppfattet som viktig, og anatomiforskning var den gang et «satsingsområde».

Anna Morandi Manzolini var anatom, forsker og underviser. Det var grei tilgang på døde mennesker i Bologna den gangen, og hun fikk lik både fra sykehuset og fra henrettede kriminelle. Hun dissekerte hundrevis og var teknisk flink. Funnene beskrev hun både i voksfigurer og tekst. Obduksjonene foregikk i hennes eget hjem, noe som visstnok var vanlig da. Man vet ikke hvilken utdanning hun hadde. Hun leste og skrev vitenskapelige notater på latin og ble raskt kjent utenfor det medisinske miljøet i Bologna. Det kom støtteerklæringer fra paven. I tillegg til at voksfigurene var anatomisk riktige, ble de også kjent som kunstnerisk verdifulle.

Bologna hadde på den tiden et godt rykte som universitetsby, med Europas eldste universitet, opprettet i 1088. På 1700-tallet var anatomiundervisningen spesielt godt kjent. Voksfigurene ble laget for kunstnere, slik at de kunne lære om menneskekroppens muskler og bevegelser. Morandi laget voksfigurer spesielt beregnet på legestudentene. Hun beskrev muskler, sener, nerver og årer i detalj. For at fremstillingen skulle blir riktig, for eksempel av årer, hendte det at hun injiserte voks i årene. Hun interesserte seg spesielt for sansene. Det finnes mange bevarte voksfigurer av øynene og deres muskler. Følelsens anatomi forsøkte hun seg også på. Hennes «følende hender» viser én hånd i smerte og én hånd avslappet idet den tar på en bløt pute. Bemerkelsesverdige er hennes studier av de mannlige genitalia og deres funksjon. Hun fikk ord på seg for å ha «fjernet fikenbladet fra de mannlige genitalia».

Morandis selvportrett er en voksbyste i full størrelse. Den ble restaurert til museets nyåpning i 2000. Hun fremstiller seg selv mens hun dissekerer en hjerne. Hennes ektefelle fikk også en voksbyste i full størrelse. Han avbildes mens han dissekerer et hjerte.

Mange av Morandis voksfigurer kan i dag ses i Palazzo Poggi, som tilhører Universitetet i Bologna.

Boken er svært detaljert og med grundig dokumentasjon. Den har nok størst interesse for medisinhistorikere, spesielt dem som er interessert $i$ anatomihistorie og universitetshistorie. Forfatteren forteller mye om opplysningstidens kvinner, slik at også kvinneforskere vil finne interessante beskrivelser her.

\section{En offentlig bedriftshelsetjeneste?}

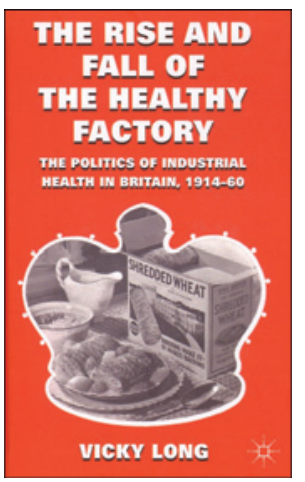

\author{
Vicky Long \\ The rise and fall of the healthy factory
}

The politics of industrial health in Britain 1914-1960. 290 s, ill. Hampshire: Palgrave Macmillan, 2010. Pris GBP 55

ISBN 978-0-230-28371-8

Under begge verdenskrigene var England preget av et sterkt statlig engasjement for å ta vare på helsen til dem som utgjorde arbeidskraften. Etter den annen verdenskrig trodde mange at den statlige interessen skulle munne ut $i$ en offentlig bedriftshelsetjeneste innenfor den planlagte National Health Service (NHS).

Vicky Long forteller om hvordan den statlige interessen forsvant etter verdenskrigene da det igjen ble nok jobbsøkere. En 50 år lang historie om forholdet mellom engelsk arbeidsliv og helsetjeneste rommer det meste av oppfatninger om hvordan kontakten burde være. Det var ikke uunngåelig, men forståelig, at bedriftshelsetjenesten i England ble overlatt til markedet og partene i arbeidslivet, med fagbevegelsen som en langt svakere part enn her i landet.

I 1944 oppfordret den engelske landsorganisasjonen, Trade Union Congress (TUC), regjeringen til å opprette en bedriftshelsetjeneste innenfor rammen av NHS, som omfattet alle sektorer av arbeidslivet, ansvarlig bare i forhold til NHS og staten. Legeforeningen, British Medical Association (BMA), støttet tanken om å inkludere arbeidshelse i den generelle helsetjenesten. Man måtte ikke skille arbeidsmiljøet fra miljøet generelt, eller arbeideren fra borgeren. Den eksisterende bedriftshelsetjenesten strakk ikke til. Den nådde f.eks. ikke mindre bedrifter. Bare en offentlig tjeneste innenfor NHS og under Helsedepartementet kunne sikre utvikling og uavhengighet, ble det sagt.

Den britiske arbeidsgiverforeningen, British Employers Confederation (BEC), mente at hovedsaken for bedriftshelsetjenesten måtte være å bidra til økt produktivitet, ettersom hele samfunnet var avhengig av den arbeidsføre arbeideren. Derfor måtte arbeidernes helse prioriteres fremfor den øvrige befolkningen og gå foran NHS, og bedriftshelsetjenesten måtte inngå i bedriftens organisasjon.

Under skiftende regjeringer konkurrerte Helsedepartementet og Arbeidsdepartementet om hvem som var mest kompetent til å uttale seg om saken. Komiteer og arbeidsgrupper kom og gikk uten nevneverdige resultater. Man fikk et mangfold av tjenestetyper og legeroller med bedriftene som oppdragsgiver: sykefraværskontrollører, livsstilprofeter, allmennpraktikere, forebyggere, skadekirurger og medisinsk sakkyndige for arbeidsgiver i rettssalen. Hva var bedriftshelsetjenestens hensikt? Å forebygge sykdom og skader, eller å redusere produksjonstap i form av sykefravær og lav ytelse? Gjaldt det å skaffe den produktive delen av befolkningen forkjørsrett til alminnelige helsetjenester, eller var det en nødvendig spesialisthelsetjeneste for grupper med spesiell helserisiko?

Norge har også fått en bedriftshelsetjeneste utenfor den nasjonale helsetjenesten. Den er markedsstyrt innenfor ganske uklare juridiske rammer og i praksis unntatt fra Helsetilsynets normale kvalitetskontroll. Om ansattes helse og personvern blir forsvarlig ivaretatt, står og faller med integritet og kompetanse hos den enkelte bedriftslege og øvrig personell. De som bekymrer seg for bedriftshelsetjenestens utvikling og tror man kan lære av andres historie, vil ha glede av denne boken.

\section{Ebba Wergeland}

Oslo 